\title{
Analysis of Perioperative Risk Factors for Complications Following Modified Radical Mastectomy- A Longitudinal Study
}

\section{ABSTRACT}

Introduction: Modern therapy for the breast cancer has evolved to include both surgical and systemic therapy. The Modified Radical Mastectomy (MRM) is the standard treatment option for most of the patients with breast cancer. Early complications are defined here as complications occurring within 30 days after surgery. The initial complications following MRM includes wound infections, seromas, chronic pain, flap necrosis and haematomas.

Aim: To study the frequency of occurrence of outcomes such as, seroma, haematoma, flap necrosis, Surgical Site Infection (SSI) following MRM and to associate the outcomes with the clinical, demographic, intraoperative and postoperative factors.

Materials and Methods: The present study was a single centre longitudinal cohort study with sample size of 72 . Patients who are admitted for MRM for carcinoma breast between January 2019 to January 2020 in Department of General Surgery, ESIC MC \& PGIMSR, Rajajinagar, Bengaluru, Karnataka, India, were taken for study after considering the inclusion and exclusion criteria. The data of risk factors collected were entered into a proforma. After surgery they were observed postoperatively for early complications. They were followed-up for a period of one month. Information was entered in Statistical Package for the Social Sciences (SPSS) software. Descriptive statistics comprising of mean, average, standard deviation, proportion, and percentage were used. Comparison of continuous data was done by Student's t-test and categorical variables were compared using Chi-square test. Variables with $\mathrm{p}$-value $<0.05$ were considered as significant risk factor.

Results: Out of the 72 patients, who underwent MRM 27 (37.5\%) developed seroma, 6 patients (8.3\%) developed SSI and 9 patients (12.5\%) developed flap necrosis. There was significant association between Seroma Formation (SF) and higher age $(p=0.026)$, higher BMI $(p=0.001)$, hypertension $(p=0.004)$ and drain volume on day 1 $(p<0.001)$. There was significant association between SSI and Diabetes Mellitus (DM) $(p=0.002)$, prolonged duration of drain $(p=0.03)$. There was significant association between flap necrosis and DM $(\mathrm{p}=0.003)$.

Conclusion: The incidence of seroma was higher in older, hypertensive and in more obese patients. It was decreased was decreased by flap fixation under muscles. The incidence of SSI and flap necrosis was higher among diabetic patients. Optimisation of glycaemia will help in reducing both.

\section{INTRODUCTION}

Breast cancer is the second most common malignancy and a major cause of cancer related death with $23 \%$ of new cases and $14 \%$ of total deaths globally [1]. Modern therapy for the breast cancer has evolved to include both surgical resection for local disease and chemotherapy, hormonal therapy and radiotherapy for the systemic disease [2]. The MRM or wide local excision is the modality of treatment option for patients with breast cancer. Early complications are defined here as complications occurring within 30 days after surgery. It is documented that initial wound complications following MRM are wound infections, seromas, chronic pain, flap necrosis and haematomas [3]. Based on different surveys, a range of $0.8-26 \%$ has been reported as the incidence rate of the surgical site complications after the breast surgeries $[4,5]$. SF is the most common postoperative complication seen following MRM with an incidence of 3-85\% [6]. Infection developing within seroma increases morbidity and often increases the financial burden to the patient [7]. Incidence rates for postoperative wound infections are variable and range from 3-19\% chronic pain in 20$30 \%$ of the cases, flap necrosis is reported between 3-32\% [8-10]. The incidence of functionally significant lymphedema after a MRM is $<10 \%$ [11]. The different factors which causes seroma, flap necrosis and wound infection have been divided into tumour factors (tumour size, lymph node status), patient factors (age, weight, comorbidities) and surgical factors (use of electrocautery/scalpel for flap dissection, duration of the surgery) [12]. Complications after mastectomy can be minimised with proper preoperative evaluation, meticulous technique, haemostasis and wound closure. In addition to the oncologic evaluation, preoperative evaluation includes assessment of patients overall physiologic condition with emphasis on tolerability of anaesthesia, Body Mass Index (BMI), diabetic status, hypertension, anemia, coagulopathy or steroid therapy, duration of surgery [13]

This study intends to find out the frequency of occurrence of outcomes such as, seroma, haematoma, flap necrosis, Surgical Site Infection (SSI) following MRM and the association between the risk factors and the complications following MRM.

\section{MATERIALS AND METHODS}

The present study was a longitudinal study, patients who were admitted in General Surgery Department in ESIC PGIMSR Bengaluru, Karnataka, India, with breast cancer Locally Advanced Breast Cancer (LABC)Stage 3A from January 2019 to January 2020 were included. It is a single centre longitudinal cohort study with sample size of 72 . Considering the incidence of complications 20\% [11] with precision of $10 \%$ and $95 \%$ confidence interval and $80 \%$ power sample size obtained was 62 . Considering $10 \%$ loss to follow-up sample size taken was 72. It was calculated using OpenEpi version 3.03. Ethical clearance was obtained from the institute, with approval number 532/L/11/12/Ethics/ESICMC\&PGIMSR/Estt.Vol..IV. 
Inclusion criteria: Study included patients with $L A B C$ stage $3 A$ and 3B (post-neoadjuvant chemotherapy) and patients who had recurrence after breast conservation surgery.

Exclusion criteria: Study excluded patients undergoing breast conservation surgery, patients with metastatic breast cancer, residual disease, pregnant ladies with carcinoma breast.

A total of 72 cases were selected. A written informed consent was taken from all patient included in the study. A detailed history taking, through clinical examination, baseline investigations including fine needle aspiration cytology, core biopsy were done for these patients. The data of risk factors collected were entered into a proforma. Patients were posted for surgery after preparing the patient and were observed postoperatively for complications and were followedup for a period of one month. Parameters studied:

1. Factors observed preoperatively: Age of the patient: a) $>45$ years; b) $<45$ years, BMl: a) $>22.5 \mathrm{~kg} / \mathrm{m}^{2}$; b) $<22.5 \mathrm{~kg} / \mathrm{m}^{2}$, preoperative serum proteins, co-morbidities like DM, hypertension.

2. Factors observed intraoperatively: Duration of surgery, modality used for dissection of flap: a) electrocautery; b) scalpel, mechanical closure of dead space done by suture fixation. Technique of skin closure: a) sutures and b) stapler

3. Postoperatively: Duration of drain in-situ: a) $>8$ days; b) $<8$ days, drain volume on postoperative day 1 , timing of starting of physiotherapy.

\section{STATISTICAL ANALYSIS}

The information collected was entered in Microsoft Excel and analysed using SPSS version 23.0 software. Independent variables were usage of electrocautery, mechanical closure of dead space and dependant variables were age, DM, hypertension, BMI, serum protein, skin closure, duration of surgery, timing of removal of drain, drain volume and timing of starting the physiotherapy. Descriptive statistics comprising of mean, average, standard deviation, proportion, and percentage were used. Comparison of continuous data was done by Student's t-test and categorical variables were compared using Chi-square test. Variables with $p$-value $<0.05$ were considered as significant risk factor.

\section{RESULTS}

Study included 71 female patients and one male patient. Majority (36.1\%) of patients were between the age group of $41-50$ years, with mean age being $51.25 \pm 10.39$ years. About $31.9 \%$ of the patients had BMl between $25-29.9 \mathrm{~kg} / \mathrm{m}^{2}$. Almost all of the patients (90.3\%) were started with upper limb physiotherapy on postoperative day 1 [Table/Fig-1]. Some of the other risk factors observed were preoperative serum proteins, the mean value of which was $7.4 \pm 0.70 \mathrm{gm} / \mathrm{dL}$ (Range: 6.729-8.131 gm/ $\mathrm{dL}$ ). The mean duration of surgery was 108.61 \pm 29.41 minutes, (range: 79.2-138.02 minutes). The mean volume of the drain volume on day 1 was $155.42 \pm 84.60 \mathrm{~mL}$. (Range: 70.818- $240.02 \mathrm{~mL}$ ). Out of the 72 patients, who underwent MRM 27 patients (37.5\%) developed seroma, 6 patients (8.3\%) developed SSI and 9 patients (12.5\%) developed flap necrosis [Table/Fig-1]. There was significant association between SF and with patients $>45$ years, with BMl $>25 \mathrm{~kg} / \mathrm{m}^{2}$, with hypertension, and with mean drain volume on day 1 [Table/Fig-2]. There was a significant association between SSI and Type 2 DM, and with prolonged drain in-situ [Table/Fig-3]. There was a significant association between flap necrosis and Type 2 DM [Table/Fig-4,5].

\begin{tabular}{|l|c|c|}
\hline Age group (years) & Frequency $(\mathrm{n})$ & Percent $(\%)$ \\
\hline$\leq 30$ & 1 & 1.4 \\
\hline $31-40$ & 9 & 12.5 \\
\hline
\end{tabular}

\begin{tabular}{|c|c|c|c|}
\hline \multicolumn{2}{|l|}{$41-50$} & 26 & 36.1 \\
\hline \multicolumn{2}{|l|}{$51-60$} & 22 & 30.5 \\
\hline \multicolumn{2}{|l|}{$61-70$} & 12 & 16.7 \\
\hline \multicolumn{2}{|l|}{$>70$} & 2 & 2.8 \\
\hline \multicolumn{2}{|l|}{ Total } & 72 & 100 \\
\hline \multicolumn{4}{|l|}{ BMI (kg/m²) } \\
\hline \multicolumn{2}{|l|}{ Underweight (<18.5) } & 1 & 1.4 \\
\hline \multicolumn{2}{|l|}{ Normal (18.5-24.9) } & 48 & 66.7 \\
\hline \multicolumn{2}{|l|}{ Preobese (25-29.9) } & 23 & 31.9 \\
\hline \multicolumn{2}{|l|}{ Total } & 72 & 100 \\
\hline \multicolumn{4}{|l|}{ Co-morbidity } \\
\hline \multicolumn{2}{|l|}{ Type 2 DM } & 14 & 19.5 \\
\hline \multicolumn{2}{|l|}{ HTN } & 22 & 30.6 \\
\hline \multicolumn{2}{|l|}{ Hypothyroidsm } & 8 & 11.1 \\
\hline \multicolumn{4}{|c|}{ Modality used for dissection of the flap } \\
\hline \multicolumn{2}{|l|}{ Cautery } & 71 & 98.6 \\
\hline \multicolumn{2}{|l|}{ Cautery, Scissors } & 1 & 1.4 \\
\hline \multicolumn{2}{|l|}{ Total } & 72 & 100 \\
\hline \multicolumn{4}{|c|}{ Mechanical closure of dead space by suture fixation } \\
\hline \multicolumn{2}{|l|}{ Done } & 7 & 9.7 \\
\hline \multicolumn{2}{|l|}{ Not done } & 65 & 90.3 \\
\hline \multicolumn{2}{|l|}{ Total } & 72 & 100 \\
\hline \multicolumn{4}{|c|}{ Timing of starting the physiotherapy } \\
\hline \multicolumn{2}{|l|}{ Day 0} & 1 & 1.4 \\
\hline \multicolumn{2}{|l|}{ Day 1} & 65 & 90.3 \\
\hline \multicolumn{2}{|l|}{ Day 2} & 5 & 6.9 \\
\hline \multicolumn{2}{|l|}{ Day 4} & 1 & 1.4 \\
\hline \multicolumn{2}{|l|}{ Total } & 72 & 100 \\
\hline \multicolumn{4}{|l|}{ Outcome/Complications } \\
\hline Seroma & & 27 & 37.5 \\
\hline SSI & & 6 & 8.3 \\
\hline Flap necrosis & & 9 & 12.5 \\
\hline & $\mathrm{N}$ & Mean & Std. deviation \\
\hline Serum protein (gm/dL) & 72 & 7.430556 & 0.7018364 \\
\hline Duration (min) & 72 & 108.61 & 29.410 \\
\hline Drain volume $(\mathrm{mL})$ & 72 & 155.42 & 84.602 \\
\hline
\end{tabular}

\begin{tabular}{|c|c|c|c|c|}
\hline Factors & Variables & $\begin{array}{c}\text { Seroma } \\
\text { present } \\
(n=27)\end{array}$ & $\begin{array}{c}\text { Seroma } \\
\text { absent } \\
(n=45)\end{array}$ & $\mathrm{p}$-value \\
\hline Age (years) & & $\begin{array}{c}54.74 \\
( \pm 8.90)\end{array}$ & $\begin{array}{l}49.16 \\
( \pm 10.7)\end{array}$ & $\begin{array}{c}0.026^{\star} \\
\text { (Student's t-test) }\end{array}$ \\
\hline \multirow{3}{*}{ BMI (kg/m²) } & $<18.5$ & 0 & 1 & \multirow{3}{*}{$\begin{array}{c}0.001^{*} \\
\text { (Chi-square) }\end{array}$} \\
\hline & $\begin{array}{c}\text { Normal } \\
(18.5-24.9)\end{array}$ & 11 & 37 & \\
\hline & $\begin{array}{l}\text { Preobese } \\
(25-29.9) \\
\end{array}$ & 16 & 7 & \\
\hline Type 2 DM & & 5 & 9 & 0.87 (Chi-square) \\
\hline HTN & & 10 & 12 & $0.004^{*}$ (Chi-square) \\
\hline Hypothyroidism & & 1 & 7 & 0.12 (Chi-square) \\
\hline $\begin{array}{l}\text { Post neoadjuvant } \\
\text { chemotherapy }\end{array}$ & & 5 & 8 & 0.93 (Chi-square) \\
\hline Serum protein & & $7.38 \pm 0.6$ & $7.46 \pm 0.75$ & $\begin{array}{c}0.64 \\
\text { (Student's t-test) }\end{array}$ \\
\hline \multirow{2}{*}{$\begin{array}{l}\text { Modality used for } \\
\text { dissection of the flap }\end{array}$} & Cautery & 27 & 44 & \multirow{2}{*}{0.43 (Chi-square) } \\
\hline & Cautery, scissors & 0 & 1 & \\
\hline \multirow{2}{*}{$\begin{array}{l}\text { Mechanical } \\
\text { closure of dead } \\
\text { space by suture } \\
\text { fixation }\end{array}$} & Done & 1 & 6 & \multirow{2}{*}{0.18 (Chi-square) } \\
\hline & Not done & 26 & 39 & \\
\hline
\end{tabular}




\begin{tabular}{|c|c|c|c|c|}
\hline \multirow{2}{*}{ Skin closure } & Staplers & 25 & 39 & \multirow{2}{*}{0.43 (Chi-square) } \\
\hline & Sutures & 2 & 6 & \\
\hline \multirow{4}{*}{$\begin{array}{l}\text { Timing of removal } \\
\text { of drain }\end{array}$} & $>8$ days & 27 & 28 & \multirow{4}{*}{0.35 (Chi-square) } \\
\hline & $5^{\text {th }}$ day & 0 & 8 & \\
\hline & $6^{\text {th }}$ day & 0 & 8 & \\
\hline & $7^{\text {th }}$ day & 0 & 1 & \\
\hline $\begin{array}{l}\text { Duration of surgery } \\
\text { (min) }\end{array}$ & & $110 \pm 28.3$ & $107 \pm 30.3$ & $\begin{array}{c}0.75 \\
\text { (Student's t-test) }\end{array}$ \\
\hline Drain volume (mL) & & $209.63 \pm 73$ & $122 \pm 74.2$ & $\begin{array}{c}<0.001^{*} \\
\text { (Student's t-test) }\end{array}$ \\
\hline \multirow{4}{*}{$\begin{array}{l}\text { Timing of starting } \\
\text { the physiotherapy }\end{array}$} & Day 0 & 1 & 0 & \multirow{4}{*}{$\begin{array}{c}0.165 \\
\text { (Chi-square) }\end{array}$} \\
\hline & Day 1 & 25 & 40 & \\
\hline & Day 2 & 1 & 4 & \\
\hline & Day 4 & 0 & 1 & \\
\hline
\end{tabular}

[Table/Fig-2]: Association between the seroma and the risk factors.

${ }^{*} \mathrm{p}<0.05$ is significant (Chi-square test and Student's t-test were used)

\begin{tabular}{|c|c|c|c|c|}
\hline Factors & Variables & $\begin{array}{l}\text { SSI Present } \\
(n=6)\end{array}$ & $\begin{array}{l}\text { SSI Absent } \\
(n=66)\end{array}$ & $p$-value \\
\hline Age (years) & & $52.83 \pm 15.2$ & $51.1 \pm 9.93$ & $\begin{array}{l}0.71 \text { (Student's } \\
\text { t-test) }\end{array}$ \\
\hline \multirow{3}{*}{$\mathrm{BMI}\left(\mathrm{kg} / \mathrm{m}^{2}\right)$} & $<18.5$ & 0 & 1 & \multirow{3}{*}{$\begin{array}{c}0.59 \\
\text { (Chi-square) }\end{array}$} \\
\hline & $\begin{array}{c}\text { Normal } \\
(18.5-24.9)\end{array}$ & 3 & 45 & \\
\hline & $\begin{array}{l}\text { Preobese } \\
(25-29.9)\end{array}$ & 3 & 20 & \\
\hline Type 2 DM & & 4 & 10 & $\begin{array}{c}0.002^{*} \\
\text { (Chi-square) }\end{array}$ \\
\hline HTN & & 3 & 19 & $\begin{array}{c}0.28 \\
\text { (Chi-square) }\end{array}$ \\
\hline Hypothyroidism & & 1 & 7 & $\begin{array}{c}0.65 \\
\text { (Chi-square) }\end{array}$ \\
\hline $\begin{array}{l}\text { Post } \\
\text { Neoadjuvant } \\
\text { chemotherapy }\end{array}$ & & 0 & 13 & $\begin{array}{c}0.23 \\
\text { (Chi-square) }\end{array}$ \\
\hline Serum Protein & & $7.11 \pm 0.77$ & $7.45 \pm 0.69$ & $\begin{array}{c}0.25 \\
\text { (Student's } \\
\text { t-test) }\end{array}$ \\
\hline \multirow{2}{*}{$\begin{array}{l}\text { Modality used } \\
\text { for dissection of } \\
\text { the flap }\end{array}$} & Cautery & 6 & 65 & \multirow{2}{*}{$\begin{array}{c}0.76 \\
\text { (Chi-square) }\end{array}$} \\
\hline & $\begin{array}{l}\text { Cautery, } \\
\text { scissors }\end{array}$ & 0 & 1 & \\
\hline \multirow{2}{*}{$\begin{array}{l}\text { Mechanical } \\
\text { closure of dead } \\
\text { space by suture } \\
\text { fixation }\end{array}$} & Done & 0 & 7 & \multirow{2}{*}{$\begin{array}{c}0.49 \\
\text { (Chi-square) }\end{array}$} \\
\hline & Not done & 6 & 59 & \\
\hline \multirow{2}{*}{ Skin closure } & Staplers & 5 & 59 & \multirow{2}{*}{$\begin{array}{c}0.65 \\
\text { (Chi-square) }\end{array}$} \\
\hline & Sutures & 1 & 7 & \\
\hline \multirow{4}{*}{$\begin{array}{l}\text { Timing of } \\
\text { removal of drain }\end{array}$} & $>8$ days & 5 & 50 & \multirow{4}{*}{$\begin{array}{c}0.03^{\star} \\
\text { (Chi-square) }\end{array}$} \\
\hline & $5^{\text {th }}$ day & 0 & 8 & \\
\hline & $6^{\text {th }}$ day & 1 & 7 & \\
\hline & $7^{\text {th }}$ day & 0 & 1 & \\
\hline $\begin{array}{l}\text { Duration of } \\
\text { surgery (min) }\end{array}$ & & $113.33 \pm 39.2$ & $108.18 \pm 28.69$ & $\begin{array}{c}0.68 \\
\text { (Student's } \\
\text { t-test) }\end{array}$ \\
\hline $\begin{array}{l}\text { Drain volume } \\
(\mathrm{mL})\end{array}$ & & $203.3 \pm 79.1$ & $151.06 \pm 84.29$ & $\begin{array}{l}0.14 \text { (Student's } \\
\text { t-test) }\end{array}$ \\
\hline \multirow{4}{*}{$\begin{array}{l}\text { Timing of } \\
\text { starting the } \\
\text { physiotherapy }\end{array}$} & Day 0 & 0 & 1 & \multirow{4}{*}{$\begin{array}{c}0.76 \\
\text { (Chi-square) }\end{array}$} \\
\hline & Day 1 & 6 & 59 & \\
\hline & Day 2 & 0 & 5 & \\
\hline & Day 4 & 0 & 1 & \\
\hline
\end{tabular}

[Table/Fig-3]: Association between the Surgical Site Infection (SSI) and risk factors. ${ }^{*} \mathrm{p}<0.05$ is significant (Chi-square test and Student's t-test used)

\section{DISCUSSION}

The complications noted in present study were, seroma, SSI and flap necrosis. SF collection under skin flaps or in the axillary dead space

\begin{tabular}{|c|c|c|c|c|}
\hline Factors & Variables & $\begin{array}{l}\text { Flap necrosis } \\
\text { present }(n=9)\end{array}$ & $\begin{array}{l}\text { Flap necrosis } \\
\text { absent }(n=63)\end{array}$ & $p$-value \\
\hline Age (years) & & $48.80 \pm 11.6$ & $51.5 \pm 10.2$ & $\begin{array}{c}0.47 \text { (Student's } \\
\text { t-test) }\end{array}$ \\
\hline \multirow{3}{*}{$\mathrm{BMI}\left(\mathrm{kg} / \mathrm{m}^{2}\right)$} & $<18.5$ & 0 & 1 & \multirow{3}{*}{$\begin{array}{c}0.65 \\
\text { (Chi-square) }\end{array}$} \\
\hline & $\begin{array}{l}\text { Normal } \\
(18.5-24.9)\end{array}$ & 5 & 43 & \\
\hline & $\begin{array}{l}\text { Preobese } \\
(25-29.9)\end{array}$ & 4 & 19 & \\
\hline Type 2 DM & & 5 & 9 & $\begin{array}{c}0.003^{\star} \\
\text { (Chi-square) }\end{array}$ \\
\hline HTN & & 5 & 17 & $\begin{array}{c}0.08 \\
\text { (Chi-square) }\end{array}$ \\
\hline Hypothyroidism & & 2 & 6 & $\begin{array}{c}0.25 \\
\text { (Chi-square) }\end{array}$ \\
\hline $\begin{array}{l}\text { Post } \\
\text { Neoadjuvant } \\
\text { chemotherapy }\end{array}$ & & 0 & 13 & $\begin{array}{c}0.13 \\
\text { (Chi-square) }\end{array}$ \\
\hline Serum protein & & $7.27 \pm 0.59$ & $7.45 \pm 0.7$ & $\begin{array}{c}0.48 \text { (Student's } \\
\text { t-test) }\end{array}$ \\
\hline \multirow{2}{*}{$\begin{array}{l}\text { Modality used } \\
\text { for dissection } \\
\text { of the flap }\end{array}$} & Cautery & 9 & 62 & \multirow{2}{*}{$\begin{array}{c}0.73 \\
\text { (Chi-square) }\end{array}$} \\
\hline & $\begin{array}{l}\text { Cautery, } \\
\text { scissors }\end{array}$ & 0 & 1 & \\
\hline \multirow{2}{*}{$\begin{array}{l}\text { Mechanical } \\
\text { closure of } \\
\text { dead space by } \\
\text { suture fixation }\end{array}$} & Done & 0 & 7 & \multirow{2}{*}{$\begin{array}{c}0.29 \\
\text { (Chi-square) }\end{array}$} \\
\hline & Not done & 9 & 56 & \\
\hline \multirow{2}{*}{ Skin closure } & Staplers & 8 & 56 & \multirow{2}{*}{$\begin{array}{c}0.9 \\
\text { (Chi-square) }\end{array}$} \\
\hline & Sutures & 1 & 7 & \\
\hline \multirow{4}{*}{$\begin{array}{l}\text { Timing of } \\
\text { removal of } \\
\text { drain }\end{array}$} & $>8$ days & 8 & 47 & \multirow{4}{*}{$\begin{array}{c}0.68 \\
\text { (Chi-square) }\end{array}$} \\
\hline & $5^{\text {th }}$ day & 1 & 7 & \\
\hline & $6^{\text {th }}$ day & 0 & 8 & \\
\hline & $7^{\text {th }}$ day & 0 & 1 & \\
\hline $\begin{array}{l}\text { Duration of } \\
\text { surgery (min) }\end{array}$ & & $112.78 \pm 11.4$ & $108.02 \pm 31.1$ & $\begin{array}{c}0.65 \text { (Student's } \\
\text { t-test) }\end{array}$ \\
\hline $\begin{array}{l}\text { Drain volume } \\
(\mathrm{mL})\end{array}$ & & $196.6 \pm 99.2$ & $149.52 \pm 81.0$ & $\begin{array}{c}0.11 \text { (Student's } \\
\text { t-test) }\end{array}$ \\
\hline \multirow{4}{*}{$\begin{array}{l}\text { Timing of } \\
\text { starting the } \\
\text { physiotherapy }\end{array}$} & Day 0 & 0 & 1 & \multirow{4}{*}{$\begin{array}{c}0.88 \\
\text { (Chi-square) }\end{array}$} \\
\hline & Day 1 & 9 & 56 & \\
\hline & Day 2 & 0 & 5 & \\
\hline & Day 4 & 0 & 1 & \\
\hline
\end{tabular}

[Table/Fig-4]: Association between flap necrosis and risk factors.

${ }^{*} p<0.05$ is significant (Chi-square test and Student's t-test used)

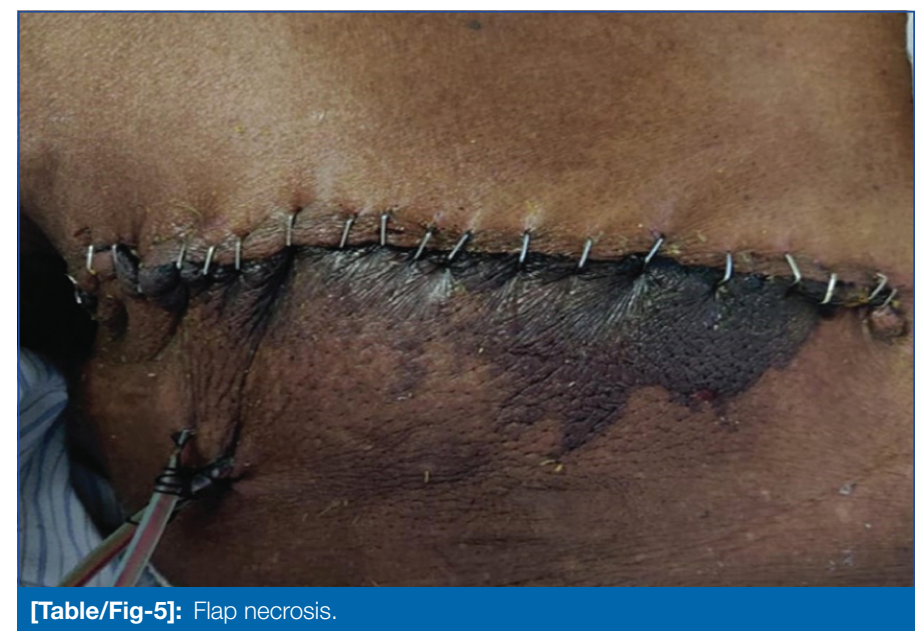

following mastectomy with axillary dissection detected clinically or by imaging [14]. It is the most common early complication [10]. It can lead to morbidity as delayed wound healing, wound infection, wound dehiscence, prolonged hospital stays, financial constraint to the patient [15]. In this study, $37.5 \%$ of patients developed seroma which was more, compared to $27 \%$ in a study by Suresh BP et al., 
and $28 \%$ in a study by Chaudhary A and Gautam S, [16,17]. As age increases, risk of SF increases as most of the patients developing the complications were $>45$ years in this study. In a study by Suresh BP et al., age $>40$ years developed seroma and Chaudhary A and Gautam S, age >62 years developed seroma [17]. Increase in BMI was found to be a significant risk factor for seroma. Overweight patients developed seroma the most in this study, which was in accordance with Suresh BP et al., (27\%) and Chaudhary A and Gautam S (28\%) studies [16,17]. Hypertension was significantly associated with seroma in this study. Similarly, in the Loo WT and Chow LW study, 8\% of patients had seroma [18]. Increased drain output on the first day of surgery is a predictive factor for SF which was also mentioned in a study by Anjani $J$ et al., [19].

Surgical Site Infection (SSI): The National Healthcare Safety Network classifies breast operations as clean procedures with an expected 1-2\% SSI incidence [20]. SSI defined by the Centers for Disease Control and Prevention (CDC) as infection related to an operative procedure that occurs at or near the surgical incision within 30 days of the procedure, or within 90 days, if prosthetic material is implanted at surgery- is among the most common preventable complication after surgery. It increases the morbidity, psychological trauma, additional cost and delay in postoperative adjuvant therapy [21]. In this study, there was significant association between diabetes and SSI (66\% of SSI was seen in diabetic patients) which was also true according to Nyaoncha A et al., and Olsen MA et al., [22,23]. Prolonged duration of drains in-situ has an increased probability of SSI, also mentioned in the Nyaoncha A et al., study [22]. Hence, drain removal is recommended as early as possible, preferably within one week. Other factors like, age, BMI, HTN, hypothyroidism, serum proteins, usage of cautery, duration of surgery, drain volume and timing of starting physiotherapy did not have any association with the formation of SSI.

Flap necrosis: It occurs when the blood supply to the skin flaps is insufficient to meet their metabolic needs. It may present as partial or full-thickness necrosis. It is a major debilitating factor as it hinders adjuvant therapy leading to morbidity among other constraints like anxiety, distress, aesthetic, and financial implications [24]. In this study, $12.5 \%$ of the patients developed flap necrosis. Flap necrosis has a significant association with T2DM as evidenced in other studies like Hultman CS and Daiza S, and Matsen CB et al., [25,26]. Therefore, care should be taken while rising flap in diabetic patient and glycaemic control is necessary. The other factors like age, BMI, HTN, hypothyroidism, usage of cautery, duration of surgery, prolonged drain in-situ timing of starting the physiotherapy did not have any association with formation of flap necrosis. As treatment of obesity takes long duration, surgery for carcinoma breast can not be postponed. Hence, expectant management of seroma in such cases is necessary and techniques like, mechanical closure of dead space should be employed in all cases of BMl $>25.01 \mathrm{~kg} / \mathrm{m}^{2}$ along with strict control of hypertension postoperatively. In diabetics, flap thickness may be maintained at the higher value $(7-8 \mathrm{~mm})$ [11] to prevent flap necrosis and adequately followed-up for the need of radiotherapy in case of recurrence. Adequate antibiotics are to be given postoperatively in patients with diabetes and consider higher antibiotics in patients with prolonged drain in-situ.

\section{Limitation(s)}

A single institute study with a small sample size of 72 was studied. If the outcomes of this study must be extended to all patients, a multicenter study with a larger sample size may be required. Also, diathermy usage was the only dissection method studied. Hence, it's causative role in complications cannot be commented upon.

\section{CONCLUSION(S)}

Seroma, SSI and flap necrosis are some of the most common complications after MRM. Important preoperative risk factors for seroma, were to age $>45$ years, HTN, overweight category and postoperatively, higher drain volume on first day increased the risk significantly. T2DM was significantly associated with SSI and flap necrosis following MRM, optimal glycaemic control, whenever feasible, should be considered before surgery. Prolonged drain insitu may be a significant risk factor for SSI and hence, early removal may be recommended.

\section{REFERENCES}

[1] Jemal A, Bray F, Center MM, Ferlay J, Ward E, Forman D. Global cancer statistics. CA: A cancer. Journal for Clinicians. 2011;61:69-90.

[2] Hudis CA, Norton L. Adjuvant drug treatment for resectable breast cancer Oncologist. 1997;2(6):351-58.

[3] Dahri FJ, Awan MS, Qazi AR, Khaskheli NM, Soomro IA. Early wound complications following modified radical mastectomy with axillary clearance. J Surg Pak (Int). 2011;16:4.

[4] Prospero E, Cavicchi A, Bacelli S, Barbadoro P, Tantucci L, D'errico MM. Surveillance for surgical site infection after hospital discharge: A surgical procedure-specific perspective. Infect Control Hospital Epidemiol. 2006;27(12):1313-17.

[5] Ruvalcaba-Limón E, Robles-Vidal C, Poitevin-Chacón A, Chávez-MacGregor M, Gamboa-Vignolle C, Vilar-Compte D. Complications after breast cancer surgery in patients treated with concomitant preoperative chemoradiation: A case-control analysis. Breast Cancer Res Treatment. 2006;95(2):147-52.

[6] Kumar S, Lal B, Misra MC. Post-mastectomy seroma: A new look into the aetiology of an old problem. I Royal Coll Surgeons Edinburgh. 1995;40(5):292-94

[7] Coveney EC, O'Dwyer PJ, Geraghty JG, O'Higgins NJ. Effect of closing dead space on seroma formation after mastectomy-A prospective randomized clinical trial. Eur J Surg Oncol. 1993;19(2):143-46.

[8] Vitug A, Newman L. Complications in breast surgery. Surg Clin North Am. 2007;87(2):431-51.

[9] Tasmuth T, Von Smitten K, Kalso E. Pain and other symptoms during the first year after radical and conservative surgery for breast cancer. $\mathrm{Br} J$ Cancer. 1996;74(12):2024-31.

[10] Larson DL, Basir Z, Bruce T. Is oncologic safety compatible with a predictably viable mastectomy skin flap. Plastic Reconstructive Surg. 2011;127(1):27-33.

[11] Fischer J, Ellison E, Upchurch G, Klimberg V, Galandiuk S, Gould J, et al. Fischer's Mastery of Surgery. China: Wolters Kluwer; 2019.616.

[12] Sorensen LT, Horby J, Friss E, Pilsgaard B, Jorgensen T. Smoking as a risk factor for wound healing and infection in breast cancer surgery. Eur J Surg Oncol. 2002;28:815-20.

[13] Vinton AL, Traverse LW, Jolly PC. Wound complications after modified radical mastectomy compared with tylectomy with axillary lymph node dissection. Am J Surg. 1991;161(5):584-88.

[14] Akinci M, Cetin B, Asian S, Kulacoglu $H$. Factors affecting seroma formation after mastectomy with full axillary dissection. Acta Chirurgica Belgica. 2009;109(4):481-83.

[15] Gonzalez EA, Saltzstein EC, Riedner CS, Nelson BK. Seroma formation following breast cancer surgery. The Breast Journal. 2003;9(5):385-88.

[16] Suresh BP, Sachin HG, Naidu M, Gopalkrishna V. A study to evaluate the factors influencing seroma formation after breast cancer surgery at tertiary care centre. Int Sur J. 2018;6(1):278-82.

[17] Chaudhary A, Gautam S. A prospective study of factors affecting seroma formation after modified radical mastectomy in patients of carcinoma of breast. Int Sur J. 2020;7(9):2919-24.

[18] Loo WT, Chow LW. Factors predicting seroma formation after mastectomy for Chinese breast cancer patients. Indian J Cancer. 2007;44(3):99.

[19] Anjani J, Amit O, Kuber S, Achal G. Factors affecting seroma formation after modified radical mastectomy in patients of carcinoma breast: A prospective study. IJSS Journal of Surgery. 2016;2(1):01-05.

[20] Olsen MA, Nickel KB, Fox IK, Margenthaler JA, Ball KE, Mines D, et al. Incidence of surgical site infection following mastectomy with and without immediate reconstruction using private insurer claims data. Infection Control \& Hospital Epidemiology. Cambridge University Press; 2015;36(8):907-14. [original e- article: https://www.cdc.gov/nhsn/pdfs/ps-analysis-resources/ImportingProceudre Data.pdf].

[21] Surgical site infections, Background. [Internet] [updated Sep 2019; 15 September]. Available from:https://psnet.ahrq.gov/primer/surgical-site-infections (e-article).

[22] Nyaoncha A, Wasike R, Ahmed M, Njihia B. Surgical site infection rates in breast cancer surgery at a University hospital in Nairobi, Kenya. Clin Oncol. 2016;1:1069. Clin Oncol. 2016;1:1069.

[23] Olsen MA, Lefta M, Dietz JR, Brandt KE, Aft R, Matthews R, et al. Risk factors for surgical site infection after major breast operation. J Am Coll Surg. 2008;207(3):326-35.

[24] Robertson SA, Jeevaratnam JA, Agrawal A, Cutress RI. Mastectomy skin flap necrosis: Challenges and solutions. Breast Cancer: Targets and Therapy. 2017;9:141. 
[25] Hultman CS, Daiza S. Skin-sparing mastectomy flap complications after breast reconstruction: Review of incidence, management, and outcome. Annals of Plastic Surgery. 2003;50(3):249-55.
[26] Matsen CB, Mehrara B, Eaton A, Capko D, Berg A, Stempel M, et al. Skin flap necrosis after mastectomy with reconstruction: A prospective study. Annals of Surgical Oncology. 2016;23(1):257-64.

PARTICULARS OF CONTRIBUTORS:

1. Resident, Department of General Surgery, ESICMC PGIMSR and Model Hospital, Bengaluru, Karnataka, India.

2. Professor and Head, Department of General Surgery, ESICMC PGIMSR and Model Hospital, Bengaluru, Karnataka, India.

NAME, ADDRESS, E-MAIL ID OF THE CORRESPONDING AUTHOR:

Dr. Aishwarya Radhakrishna,

G 703, $7^{\text {th }}$ Floor, ESIC PG Hostel, $41^{\text {st }}$ Cross, Rajajinagar $3^{\text {rd }}$ Block,

Bengaluru-560010, Karnataka, India.

E-mail: radhaaishwarya69@gmail.com

\section{AUTHOR DECLARATION:}

- Financial or Other Competing Interests: None

- Was Ethics Committee Approval obtained for this study? Yes

- Was informed consent obtained from the subjects involved in the study? Yes

- For any images presented appropriate consent has been obtained from the subjects. Yes
PLAGIARISM CHECKING METHODS: ${ }^{[\mathrm{ain} H \mathrm{H} \text { tal.] }}$

- Plagiarism X-checker: Jan 02, 2021

- Manual Googling: Mar 15, 2021

- iThenticate Software: Apr 01, 2021 (16\%)
ETYMOLOGY: Author Origin

Date of Acceptance: Mar 16, 2021

Date of Publishing: Jul 01, 2021 